\title{
Umbilical cord blood cells for treatment of cerebral palsy; timing and treatment options
}

\author{
Courtney A. McDonald ${ }^{1}$, Michael C. Fahey ${ }^{2}$, Graham Jenkin ${ }^{1}$ and Suzanne L. Miller ${ }^{1}$
}

Cerebral palsy is the most common cause of physical disability in children, and there is no cure. Umbilical cord blood (UCB) cell therapy for the treatment of children with cerebral palsy is currently being assessed in clinical trials. Although there is much interest in the use of UCB stem cells for neuroprotection and neuroregeneration, the mechanisms of action are not fully understood. Further, UCB contains many stem and progenitor cells of interest, and we will point out that individual cell types within UCB may elicit specific effects. UCB is a clinically proven source of hemotopoietic stem cells (HSCs). It also contains mesenchymal stromal cells (MSCs), endothelial progenitor cells (EPCs), and immunosupressive cells such as regulatory $T$ cells (Tregs) and monocyte-derived supressor cells. Each of these cell types may be individual candidates for the prevention of brain injury following hypoxic and inflammatory events in the perinatal period. We will discuss specific properties of cell types in UCB, with respect to their therapeutic potential and the importance of optimal timing of administration. We propose that tailored cell therapy and targeted timing of administration will optimize the results for future clinical trials in the neuroprotective treatment of perinatal brain injury.

C erebral palsy is the most common physical disability in childhood caused by damage to the developing brain that occurs in the antenatal, perinatal, or early postnatal period. Cerebral palsy describes a complex set of motor symptoms, with disability ranging from mild motor coordination dysfunction through to significant hemiplegia or quadriplegia. The heterogeneity of cerebral palsy reflects a spectrum of neuropathologies that differentially affect the preterm or term infant brain. The motor disabilities that define cerebral palsy are also often coexistent with other serious problems-one in two children with cerebral palsy has intellectual disabilities including cognition, memory, learning, and behavior deficits; one in four has epilepsy; one in four cannot talk; and one in four are incontinent (1). Accordingly, cerebral palsy places a profound burden on families, health-care systems, and society. There is no cure for cerebral palsy and, although it is encouraging that the prevalence of the condition indicates a downward trend in some recently published figures, this trend is not apparent globally $(2,3)$.

Stem cells have received widespread attention and interest for their potential to improve multiple conditions or disease states (4). This has resulted in many patients and families investing large amounts of money to travel overseas for stem cell treatment in the hope of finding a cure. People with cerebral palsy, and particularly the parents of infants or children with cerebral palsy, are keenly pursuing stem cell-related therapies. This is reflected in the worldwide statistics showing that cerebral palsy is ranked second (after multiple sclerosis) as the most common condition treated with stem cells (5). It does, however, remain that stem cell treatments for cerebral palsy are currently unproven, the optimal source of stem cells is not yet known, and stem cell treatment is not readily available and is often very costly, particularly if patients or families are traveling overseas to receive treatment. It is, therefore, the responsibility of the scientific and medical community to exercise caution at this stage, and to robustly examine stem cell efficacy, timing, and optimal cell type to guide clinical practice and inform community interest. In this review we will examine the current understanding of the use of stem cells in the treatment of the brain injury that underlies cerebral palsy, with a principal focus on the neuroprotective/neuroregenerative potential of umbilical cord blood (UCB) cells.

When considering stem cell therapies, given the large number of stem and progenitor cell types that are being tested in preclinical studies, it can be hard to determine which cell source may be best suited to a specific condition. For treatment of many disorders, and in particular perinatal brain injury, there are multiple advantages for the use of UCB mononuclear cells, including their low immunogenicity and, therefore, low risk of rejection and development of graft vs. host disease (6), making UCB cells a relatively safe source for transplantation. UCB is also readily available in large quantities, is usually discarded at birth, and can withstand long-term cryopreservation, maintaining up to $90 \%$ viable cell recovery post thaw (7). Most importantly for translation, UCB has been used clinically for almost 30 years (8) and is now routinely used to treat acute leukemia, aplastic anemia,

\footnotetext{
${ }^{1}$ The Ritchie Centre, Hudson Institute of Medical Research and Department of Obstetrics and Gynaecology, Monash University, Clayton, Victoria, Australia; ${ }^{2}$ Department of Paediatrics, Monash University, Clayton, Victoria, Australia. Correspondence: Suzanne L. (suzie.miller@monash.edu)

Received 16 June 2017; accepted 19 September 2017; advance online publication 1 November 2017. doi:10.1038/pr.2017.236
} 


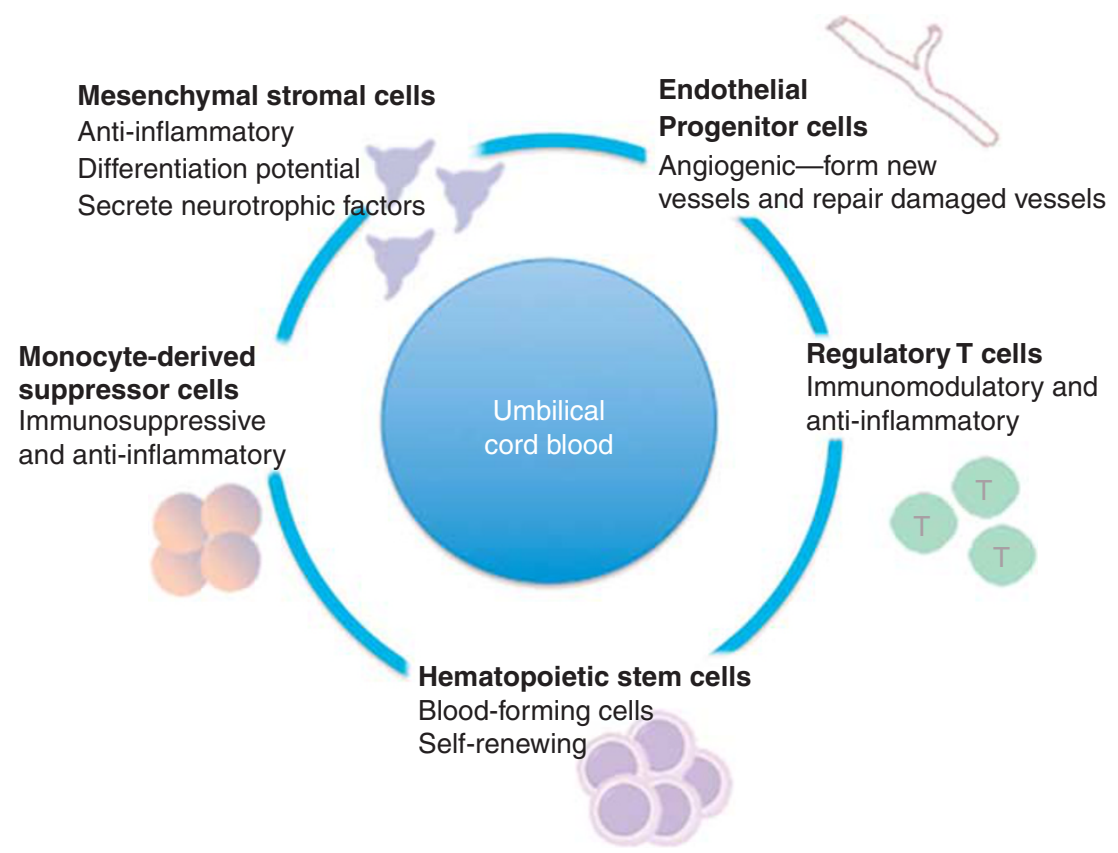

Figure 1. Principal stem and progenitor cells found in umbilical cord blood (UCB), and their main actions. A diagrammatic representation of the five key stem and progenitor cell subtypes found in UCB, that are likely to mediate the neuroprotective or neuroregenerative benefits of UCB. These include mesenchymal stromal cells (MSCs), endothelial progenitor cells (EPCs), hematopoietic stem cells (HSCs), monocyte-derived suppressor cells (MDSCs), and regulatory T cells (Tregs). Listed below each cell type are their most commonly described features.

lymphomas, thalassemia, and sickle cell disease $(9,10)$. Given the current clinical use and potential applications of UCB, the first UCB banks were established in the early 1990s ( (ref. 11)) and, since then, public and private UCB banks have emerged around the world, and are very prevalent in high-resource countries.

UCB is a rich source of stem and progenitor cells including hematopoietic stem cells (HSCs), mesenchymal stromal cells (MSCs), endothelial progenitor cells (EPCs), and immunosupressive cells, such as regulatory $\mathrm{T}$ cells (Tregs) and monocytederived suppressor cells (MDSCs; Figure 1) $(12,13)$. UCB cells can influence local tissue repair via secretion of a range of important trophic factors such as cytokines (interleukin (IL)-6, IL-8, IL-10, and monocyte chemoattractant protein-1) (14), angiogenic factors (vascular endothelial growth factor and angiogenin) (15), and neurotrophic factors (brain-derived neurotrophic factor, nerve growth factor, glial cell line-derived neurotrophic factor) (14,16). Furthermore, many of the individual cell types composing UCB may act in a paracrine manner when transplanted, secreting soluble factors capable of direct stimulation and/or proliferation of neural stem cells (NSCs), or by stimulating endogenous cells to release reparatory factors (12).

The broad neuroprotective properties of UCB are also mediated by anti-inflammatory and anti-apoptotic properties, together with effects on cell survival and angiogenesis (13). UCB cells have now been shown to directly protect neurons (17), oligodendrocytes (18), and astrocytes (19) from undergoing apoptosis. Further, it has been demonstrated that, under certain in vitro conditions, UCB cells can differentiate down the neural lineage (15). As a result, UCB cells are currently being examined in clinical trials for a range of adverse conditions such as perinatal brain injury, established cerebral palsy, and adult stroke, in addition to their established benefits for blood-related diseases.

Rodent models of adult stroke or traumatic brain injury were the first to lay the foundation to investigate the potential of UCB cells to reduce brain injury. These studies provided promising data that UCB cells could migrate to sites of injury within the brain (20) and, when given intravenously, reduced functional deficits (21) and protected against white matter injury (18). In turn, subsequent studies in rats have explored the neuroprotective potential of UCB cells in perinatal brain injury. When UCB cells are given within the first $24 \mathrm{~h}$ after hypoxic-ischemic (HI) injury in term-equivalent rat pups, they improve both pathology and motor control, mediated by a reduction in neuronal degeneration, apoptosis, and microglial activation (22), as well as reducing spastic paresis and improving walking patterns $(13,23,24)$. More recently, it has been shown that UCB-derived MSCs can augment the neuroprotective benefits of hypothermia in neonatal rats exposed to hypoxia-ischemia (25) - an important observation, given that therapeutic hypothermia is now the standard of care for term infants diagnosed with $\mathrm{HI}$ encephalopathy (HIE).

\section{CLINICAL DATA SUPPORTING UCB THERAPY FOR CEREBRAL PALSY}

The promising data derived from rodent studies on the treatment of brain injury with UCB cells initially underpinned 
Table 1. Clinical trials using UCB for the treatment of $C P$ and ischemic brain injury in the neonate

\begin{tabular}{|c|c|c|c|c|c|c|c|c|c|c|c|}
\hline \multirow[t]{2}{*}{ Status } & \multirow[t]{2}{*}{ Study name } & \multirow[t]{2}{*}{ Sponsor } & \multirow[t]{2}{*}{ Study type } & \multirow[t]{2}{*}{ Primary outcome } & \multicolumn{3}{|c|}{ Cell administration } & \multirow[t]{2}{*}{ Age } & \multirow{2}{*}{$\begin{array}{l}\text { Inclusion } \\
\text { criteria }\end{array}$} & \multirow[t]{2}{*}{ \# Patients } & \multirow[t]{2}{*}{ Clinical trial ID } \\
\hline & & & & & Source & Dose & Route & & & & \\
\hline Recruiting & $\begin{array}{l}\text { Safety and } \\
\text { Effectiveness of Cord } \\
\text { Blood Stem Cell } \\
\text { Infusion for the } \\
\text { Treatment of CP in } \\
\text { Children }\end{array}$ & $\begin{array}{l}\text { Augusta } \\
\text { University, USA }\end{array}$ & $\begin{array}{l}\text { Blinded, } \\
\text { crossover, } \\
\text { placebo- } \\
\text { controlled }\end{array}$ & Safety & Autologous & $\begin{array}{l}>10 \mathrm{M} / \mathrm{kg} \\
\text { body weight }\end{array}$ & IV & $\begin{array}{l}2-12 \\
\text { years }\end{array}$ & $\begin{array}{l}\text { Any } \\
\text { severity of } \\
\text { CP }\end{array}$ & 20 & NCT01072370 \\
\hline Completed & $\begin{array}{l}\text { UCB therapy for } \\
\text { children with CP }\end{array}$ & $\begin{array}{l}\text { Bundang CHA } \\
\text { Hospital, Korea }\end{array}$ & $\begin{array}{l}\text { Open label, } \\
\text { single group } \\
\text { assignment }\end{array}$ & $\begin{array}{l}\text { Changes in motor } \\
\text { performance, changes } \\
\text { in gross motor function }\end{array}$ & $\begin{array}{l}\text { Allogeneic } \\
\text { +rehabilitation }\end{array}$ & Unknown & IV/IA & $\begin{array}{l}6 \\
\text { Months } \\
\text { to } 20 \\
\text { years }\end{array}$ & $\begin{array}{l}\text { Any } \\
\text { severity of } \\
\text { CP }\end{array}$ & 17 & NCT01639404 \\
\hline Completed & UCB therapy for $C P$ & $\begin{array}{l}\text { Bundang CHA } \\
\text { Hospital, Korea }\end{array}$ & $\begin{array}{l}\text { Randomized, } \\
\text { double blind, } \\
\text { placebo- } \\
\text { controlled }\end{array}$ & $\begin{array}{l}\text { Changes in motor } \\
\text { performance, changes } \\
\text { in gross motor function }\end{array}$ & $\begin{array}{l}\text { Allogeneic } \\
\text { +rehabilitation }\end{array}$ & Unknown & IV/IA & $\begin{array}{l}6 \\
\text { Months } \\
\text { to } 20 \\
\text { years }\end{array}$ & $\begin{array}{l}\text { Any } \\
\text { severity of } \\
\text { CP }\end{array}$ & 37 & NCT01528436 \\
\hline Completed & $\begin{array}{l}\text { Allogenic UCB and } \\
\text { erythropoietin } \\
\text { combination therapy } \\
\text { for } \mathrm{CP}\end{array}$ & $\begin{array}{l}\text { Bundang CHA } \\
\text { Hospital, Korea }\end{array}$ & $\begin{array}{l}\text { Randomized, } \\
\text { double blind, } \\
\text { placebo- } \\
\text { controlled }\end{array}$ & $\begin{array}{l}\text { Changes in motor } \\
\text { performance, changes } \\
\text { in gross motor function }\end{array}$ & Allogeneic+EPO & $\begin{array}{l}>30 \mathrm{M} / \mathrm{kg} \\
\text { body weight }\end{array}$ & IV/IA & $\begin{array}{l}10 \\
\text { Months } \\
\text { to } 10 \\
\text { years }\end{array}$ & $\begin{array}{l}\text { Any } \\
\text { severity of } \\
\text { CP }\end{array}$ & 105 & NCT01193660 \\
\hline Recruiting & $\begin{array}{l}\text { Granulocyte colony- } \\
\text { stimulating factor and } \\
\text { autologous cord blood } \\
\text { infusion in CP }\end{array}$ & $\begin{array}{l}\text { Hanyang } \\
\text { University Seoul } \\
\text { Hospital, Korea }\end{array}$ & $\begin{array}{l}\text { Randomized, } \\
\text { double blind }\end{array}$ & $\begin{array}{l}\text { Safety with repeated } \\
\text { G-CSF injections }\end{array}$ & Autologous & Unknown & Not clear & $\begin{array}{l}2-10 \\
\text { Years }\end{array}$ & $\begin{array}{l}\text { Non- } \\
\text { severe CP }\end{array}$ & 88 & NCT02866331 \\
\hline $\begin{array}{l}\text { Active, not } \\
\text { recruiting }\end{array}$ & $\begin{array}{l}\text { Assessment of the } \\
\text { safety of allogeneic } \\
\text { UCB infusions in } \\
\text { children with CP }\end{array}$ & $\begin{array}{l}\text { Duke University } \\
\text { Medical Center, } \\
\text { USA }\end{array}$ & $\begin{array}{l}\text { Open label, } \\
\text { single group } \\
\text { assignment }\end{array}$ & Safety & $\begin{array}{l}\text { Allogeneic } \\
\text { (sibling } \\
\text { matched; first } \\
\text { six HLA- } \\
\text { matched, next } \\
\text { nine half- } \\
\text { matched) }\end{array}$ & Unknown & IV & $\begin{array}{l}12 \\
\text { Months } \\
\text { to } 6 \\
\text { years }\end{array}$ & $\begin{array}{l}\text { Any } \\
\text { severity of } \\
C P\end{array}$ & 15 & NCT02599207 \\
\hline Completed & $\begin{array}{l}\text { A randomized study of } \\
\text { autologous UCB } \\
\text { reinfusion in children } \\
\text { with } C P\end{array}$ & $\begin{array}{l}\text { Duke University } \\
\text { Medical Center, } \\
\text { USA }\end{array}$ & $\begin{array}{l}\text { Randomized, } \\
\text { double blind } \\
\text { cross-over }\end{array}$ & $\begin{array}{l}\text { Improvement of } \\
\text { standardized measures } \\
\text { of neurodevelopmental } \\
\text { function at } 2 \text { years }\end{array}$ & Autologous & $\begin{array}{l}>10 \mathrm{M} / \mathrm{kg} \\
\text { body weight }\end{array}$ & IV & $\begin{array}{l}12 \\
\text { Months } \\
\text { to } 6 \\
\text { years }\end{array}$ & $\begin{array}{l}\text { Any } \\
\text { severity of } \\
\text { CP }\end{array}$ & 63 & NCT01147653 \\
\hline Unknown & $\begin{array}{l}\text { Allogeneic UCB therapy } \\
\text { in children with CP }\end{array}$ & $\begin{array}{l}\text { Bundang CHA } \\
\text { Hospital, Korea }\end{array}$ & $\begin{array}{l}\text { Open label, } \\
\text { single group } \\
\text { assignment }\end{array}$ & $\begin{array}{l}\text { Cytokine analysis, } \\
\text { changes in motor } \\
\text { performance, changes } \\
\text { in gross motor function, } \\
\text { cognitive and motor } \\
\text { neurodevelopment }\end{array}$ & $\begin{array}{l}\text { Allogeneic (HLA } \\
\text { mismatch) }\end{array}$ & $\begin{array}{l}>30 \mathrm{M} / \mathrm{kg} \\
\text { body weight }\end{array}$ & Not clear & $\begin{array}{l}\text { Up to } 15 \\
\text { years }\end{array}$ & $\begin{array}{l}\text { Any } \\
\text { severity of } \\
\text { CP }\end{array}$ & 18 & NCT02025972 \\
\hline Recruiting & $\begin{array}{l}\text { Stem cells in umbilical } \\
\text { blood infusion for } \mathrm{cp} \\
\text { (scubi-CP) }\end{array}$ & $\begin{array}{l}\text { Murdoch } \\
\text { Childrens } \\
\text { Research } \\
\text { Institute, Australia }\end{array}$ & $\begin{array}{l}\text { Open label, } \\
\text { single group } \\
\text { assignment }\end{array}$ & Safety & $\begin{array}{l}\text { Allogeneic } \\
\text { (sibling- } \\
\text { matched) }\end{array}$ & $\begin{array}{l}>10 \mathrm{M} / \mathrm{kg} \\
\text { body weight }\end{array}$ & IV & $\begin{array}{l}1-16 \\
\text { Years }\end{array}$ & $\begin{array}{l}\text { Any } \\
\text { severity of } \\
\text { CP }\end{array}$ & 12 & NCT03087110 \\
\hline
\end{tabular}




\begin{tabular}{|c|c|c|c|c|c|c|c|c|c|c|c|}
\hline \multirow[t]{2}{*}{ Status } & \multirow[t]{2}{*}{ Study name } & \multirow[t]{2}{*}{ Sponsor } & \multirow[t]{2}{*}{ Study type } & \multirow[t]{2}{*}{ Primary outcome } & \multicolumn{3}{|c|}{ Cell administration } & \multirow[t]{2}{*}{ Age } & \multirow{2}{*}{$\begin{array}{c}\text { Inclusion } \\
\text { criteria }\end{array}$} & \multirow[t]{2}{*}{ \# Patients } & \multirow[t]{2}{*}{ Clinical trial ID } \\
\hline & & & & & Source & Dose & Route & & & & \\
\hline $\begin{array}{l}\text { Active, not } \\
\text { recruiting }\end{array}$ & $\begin{array}{l}\text { Safety and } \\
\text { effectiveness of banked } \\
\text { cord blood or bone } \\
\text { morrow stem cells in } \\
\text { children with Cp (act } \\
\text { for CP) }\end{array}$ & $\begin{array}{l}\text { The University of } \\
\text { Texas Health } \\
\text { Science Center, } \\
\text { Houston, USA }\end{array}$ & $\begin{array}{l}\text { Randomized, } \\
\text { double blind } \\
\text { Cross-over }\end{array}$ & Safety & $\begin{array}{l}\text { Autologous } \\
\text { (UCB or bone } \\
\text { marrow) }\end{array}$ & $\begin{array}{l}>10 \mathrm{M} / \mathrm{kg} \\
\text { body weight }\end{array}$ & IV & $\begin{array}{l}2-10 \\
\text { Years }\end{array}$ & $\begin{array}{l}\text { Any } \\
\text { severity of } \\
\text { CP }\end{array}$ & 20 & NCT01988584 \\
\hline Unknown & $\begin{array}{l}\text { Allogeneic UCB therapy } \\
\text { with erythropoietin in } \\
\text { children with CP }\end{array}$ & $\begin{array}{l}\text { Bundang CHA } \\
\text { Hospital, Korea }\end{array}$ & $\begin{array}{l}\text { Randomized, } \\
\text { double blind, } \\
\text { placebo- } \\
\text { controlled }\end{array}$ & $\begin{array}{l}\text { Changes in motor } \\
\text { performance, changes } \\
\text { in gross motor function, } \\
\text { cognitive and motor } \\
\text { neurodevelopment }\end{array}$ & $\begin{array}{l}\text { Allogeneic (HLA } \\
\text { mismatch)+EPO }\end{array}$ & $\begin{array}{l}>30 \mathrm{M} / \mathrm{kg} \\
\text { body weight }\end{array}$ & Not clear & $\begin{array}{l}10 \\
\text { Months } \\
\text { to } 6 \\
\text { years }\end{array}$ & $\begin{array}{l}\text { Any } \\
\text { severity of } \\
\text { CP }\end{array}$ & 120 & NCT01991145 \\
\hline Unknown & $\begin{array}{l}\text { Combination therapy of } \\
\text { cord blood and G-CSF } \\
\text { for patients with brain } \\
\text { injury or } \\
\text { neurodegenerative } \\
\text { disorders }\end{array}$ & $\begin{array}{l}\text { Bundang CHA } \\
\text { Hospital, Korea }\end{array}$ & $\begin{array}{l}\text { Open label, } \\
\text { single group } \\
\text { assignment }\end{array}$ & $\begin{array}{l}\text { Changes in motor } \\
\text { performance, changes } \\
\text { in gross motor function }\end{array}$ & $\begin{array}{l}\text { Allogeneic+G- } \\
\text { CSF }\end{array}$ & Unknown & Not clear & $\begin{array}{l}19 \text { Years } \\
\text { or older }\end{array}$ & $\begin{array}{l}\text { Any } \\
\text { severity of } \\
\text { CP }\end{array}$ & $\begin{array}{l}10 \text { (CP, ALS, } \\
\text { Parkinsons, } \\
\text { brain injury) }\end{array}$ & NCT02236065 \\
\hline Unknown & $\begin{array}{l}\text { Autologous stem cells } \\
\text { in newborns with } \\
\text { oxygen deprivation }\end{array}$ & $\begin{array}{l}\text { Hospital } \\
\text { Universitario, } \\
\text { Mexico }\end{array}$ & $\begin{array}{l}\text { Open label, } \\
\text { single group } \\
\text { assignment }\end{array}$ & $\begin{array}{l}\text { Safety at } 1 \text { week and } 1 \\
\text { year clinical assessment }\end{array}$ & Autologous & Unknown & IV & $\begin{array}{l}\text { Within } \\
\text { first } 48 \mathrm{~h} \\
\text { after } \\
\text { birth }\end{array}$ & HIE & 20 & NCT01506258 \\
\hline $\begin{array}{l}\text { Not yet } \\
\text { recruiting }\end{array}$ & $\begin{array}{l}\text { Autologous cord blood } \\
\text { and human placental- } \\
\text { derived stem cells in } \\
\text { neonates with severe } \\
\text { HIE (HPDSC+HIE) }\end{array}$ & $\begin{array}{l}\text { New York Medical } \\
\text { College, USA }\end{array}$ & $\begin{array}{l}\text { Open label, } \\
\text { single group } \\
\text { assignment }\end{array}$ & Safety and tolerability & Autologous & Unknown & IV & $\begin{array}{l}\text { Within } \\
\text { first } \\
7 \text { days } \\
\text { after } \\
\text { birth }\end{array}$ & Severe HIE & 20 & NCT02434965 \\
\hline Recruiting & $\begin{array}{l}\text { A multi-site study of } \\
\text { autologous cord blood } \\
\text { cells for HIE }\end{array}$ & $\begin{array}{l}\text { Duke University } \\
\text { Medical Center, } \\
\text { USA }\end{array}$ & $\begin{array}{l}\text { Randomized, } \\
\text { double blind, } \\
\text { placebo- } \\
\text { controlled }\end{array}$ & $\begin{array}{l}\text { Survival at } 1 \text { year, } \\
\text { Bayley assessment }\end{array}$ & Autologous & $\begin{array}{l}\text { Two doses of } \\
\text { unknown } \\
\text { concentration }\end{array}$ & IV & $\begin{array}{l}\text { Within } \\
\text { first } 48 \mathrm{~h} \\
\text { after } \\
\text { birth }\end{array}$ & $\begin{array}{l}\text { Moderate } \\
\text { to severe } \\
\text { HIE }\end{array}$ & 160 & NCT02612155 \\
\hline Completed & $\begin{array}{l}\text { Cord blood for neonatal } \\
\text { HIE }\end{array}$ & $\begin{array}{l}\text { Duke University } \\
\text { Medical Center, } \\
\text { USA }\end{array}$ & $\begin{array}{l}\text { Open label, } \\
\text { single group } \\
\text { assignment }\end{array}$ & Safety and feasibility & Autologous & $\begin{array}{l}50 \mathrm{M} / \mathrm{kg} \text { (up } \\
\text { to four doses) }\end{array}$ & IV & $\begin{array}{l}\text { Within } \\
\text { first } \\
14 \text { days } \\
\text { after } \\
\text { birth }\end{array}$ & $\begin{array}{l}\text { Moderate } \\
\text { to severe } \\
\text { HIE }\end{array}$ & 52 & NCT00593242 \\
\hline Completed & $\begin{array}{l}\text { Autologous cord blood } \\
\text { cells for brain injury in } \\
\text { term newborns }\end{array}$ & $\begin{array}{l}\text { National } \\
\text { University } \\
\text { Hospital, } \\
\text { Singapore }\end{array}$ & $\begin{array}{l}\text { Open label, } \\
\text { single group } \\
\text { assignment }\end{array}$ & Safety & Autologous & Unknown & Not clear & $\begin{array}{l}\text { Within } \\
\text { first } 72 \mathrm{~h} \\
\text { after } \\
\text { birth }\end{array}$ & $\begin{array}{l}\text { Moderate } \\
\text { to severe } \\
\text { HIE }\end{array}$ & 2 & NCT01649648 \\
\hline $\begin{array}{l}\text { Not yet } \\
\text { recruiting }\end{array}$ & $\begin{array}{l}\text { Neonatal HIE: safety } \\
\text { and feasibility study of } \\
\text { a curative treatment } \\
\text { with autologous cord } \\
\text { blood stem cells } \\
\text { (NEOSTEM) }\end{array}$ & $\begin{array}{l}\text { Assistance } \\
\text { Publique } \\
\text { Hopitaux De } \\
\text { Marseille, France }\end{array}$ & $\begin{array}{l}\text { Open label, } \\
\text { single group } \\
\text { assignment }\end{array}$ & Safety & Autologous & Unknown & Not clear & $\begin{array}{l}\text { Within } \\
\text { first } 72 \mathrm{~h} \\
\text { after } \\
\text { birth }\end{array}$ & HIE & 20 & NCT02881970 \\
\hline
\end{tabular}


the commencement of clinical trials to investigate the therapeutic potential for UCB cells for cerebral palsy. Currently, there are 21 clinical trials investigating UCB therapy for cerebral palsy, or brain injury in neonates (with HIE), including six completed studies (clinicaltrials.gov; Table 1). Recently, a meta-analysis was performed investigating all clinical trials that had published the use of stem cells as a therapy for established cerebral palsy (26). The metaanalysis examined all stem cell sources, including olfactory ensheathing cells, neural progenitor cells, and allogeneic UCB. Only randomized controlled trials and controlled clinical trials were considered, of which five trials met the selection criteria. The authors concluded that, when children with cerebral palsy were treated with stem cells, there was a significant intervention effect at a short-term (6 months) follow-up. Most interestingly, the effect was greatest for UCB cells, compared with any other cell types (26).

Although such analysis is encouraging, only a small number of clinical trials that all have relatively small sample sizes have been completed using UCB cells for treatment of cerebral palsy. In addition, many of the listed clinical trials are openlabel, single-group studies that have the primary outcome of safety (12 of 21), with 5 of 21 being randomized controlled trials (Table 1). Safety studies are important and are the necessary first step to progress any new therapy through ethics and governance bodies, and six completed studies now report safety in $>200$ patients. Critical questions that now remain include-are UCB cells efficacious to reduce cerebral palsy? What is their mechanism/s of action? When is the best time to treat? How many cells and doses should be administered? What is the best cell type? And should we use autologous or allogeneic cells? Taken together, these questions are difficult to answer in a timely manner in a clinical setting.

\section{POTENTIAL OF UCB FOR REDUCING PERINATAL BRAIN INJURY AND CEREBRAL PALSY; PRECLINICAL LARGE ANI- MAL EVIDENCE}

Preclinical studies in animal models that use a controlled and standardized insult are considered gold standard in the development of therapies from bench to bedside. In addition, a review by Bennet et al. (27) recommended that studies in large animal models are crucial to confirm the safety and, most importantly, efficacy of cell therapies to reduce perinatal brain injury and cerebral palsy. To date, just a handful of studies have assessed the efficacy of UCB cells in large animal models of perinatal brain injury (Table 2). These studies are heterogenous in their use of animal models (sheep and rabbits), their cell source (human or ovine UCB cells), route of administration, and developmental timing of injury (preterm or term). However, it is notable that results from these large animal studies indicate that early administration of UCB cells, soon after HI perinatal brain injury, confers neuroprotective benefits for brain biochemistry (magnetic resonance spectroscopy (MRS) measures), neuropathology, and functional outcomes (28-30). 
Drobyshevsky et al. (29) was the first published study assessing UCB therapy in a large animal (rabbit) model of perinatal brain injury. In this study, human UCB mononuclear cells were administered in a preterm model of $\mathrm{HI}$ brain injury. Importantly, they compared two doses of cells to determine a dose response; a low dose (2.5 million, equivalent to $\sim 45$ million human UCB cells $/ \mathrm{kg}$ ) and a high dose (5 million, equivalent to $\sim 90$ million cells $/ \mathrm{kg}$ ). Neurobehavioral assessment performed at 5 and 11 days after birth showed that the high dose of UCB had greater efficacy than the lower dose. Unfortunately, the experiments were performed separately and, therefore, no direct comparisons could be made between the two doses and any conclusions made on the effect of dosage needs to be confirmed. Moreover, this study used a xenogeneic transplantation model where human UCB cells were given to rabbits. Whereas previous studies have used human cells in rodent models $(22,23)$ and have been shown to be efficacious and likely to evade major histocompatibility complex incompatibility, there is still an increased risk of immunological reaction and clearance of the cells before they have had time to be effective. For this reason, studies investigating autologous and allogeneic transplantation from the same species are necessary.

Aridas et al. (28) examined the use of autologous UCB therapy in a lamb model of birth asphyxia and HIE. A significant finding from this study was the restoration of normal brain biochemical profiles with UCB treatment, as assessed using MRS, particularly for lactate: $\mathrm{N}$-acetyl aspartate (NAA) ratio (Figure 2). Clinically, MRS is often assessed at 57 days after perinatal asphyxia and an increase in the ratio of lactate:NAA is considered a reliable biomarker of HIE and predicts death or disability at 12 months of age (31). In the study of Aridas et al., UCB mononuclear cells were

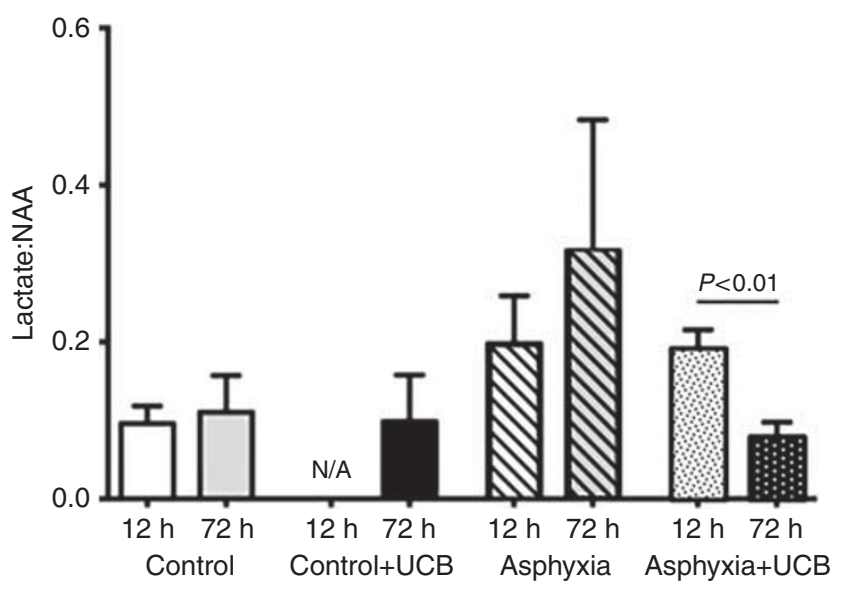

Figure 2. Umbilical cord blood (UCB) improves the brain biochemical profile of lactate: $\mathrm{N}$-acetyl aspartate (NAA) after asphyxia. Magnetic resonance spectroscopy (MRS) was performed at 12 and $72 \mathrm{~h}$ following a severe asphyxic insult at birth in term lambs. UCB was administered intra-arterially at $12 \mathrm{~h}$, immediately before the first magnetic resonance spectroscopy (MRS). Lambs that received UCB therapy demonstrated a significant decrease in brain lactate:NAA from 12 to $72 \mathrm{~h}$, whereas lactate:NAA continued to increase in the non-treated asphyxia lambs. Adapted from Aridas et al. (28). 
administered intra-arterially (via the brachial artery) at $12 \mathrm{~h}$ after a severe asphyxic insult at birth, and MRS was initially performed at $12 \mathrm{~h}$, within minutes of UCB cells being given, when an altered brain biochemical profile had already been established before cell administration. MRS was then performed again at $72 \mathrm{~h}$ post asphyxia, and it was observed that UCB therapy reduced the lactate:NAA ratio by more than $50 \%$ compared with results at $12 \mathrm{~h}$ and compared with untreated asphyxia lambs, indicating a reversal of injurious pathways after UCB therapy (Figure 2, adapted from (ref. 28)). Histopathological analysis was performed on tissue collected $72 \mathrm{~h}$ post $\mathrm{HI}$ and, in all regions of the brain assessed, autologous UCB therapy reduced caspase-3-induced apoptosis, microglial inflammation, and astrogliosis (29). A limitation of this study was that animals were only maintained for $72 \mathrm{~h}$ after birth asphyxia and, therefore, no long-term outcomes were available. Further research of long-term outcomes of such treatment is, therefore, warranted.

A second sheep study by Li et al. (30) used a preterm HI model of brain injury and administration of allogeneic term $\mathrm{UCB}$ at two time points, either at $12 \mathrm{~h}$ or at 5 days after $\mathrm{HI}$ injury. The most significant findings in this study related to white matter brain regions, where UCB therapy at $12 \mathrm{~h}$ was able to protect oligodendrocytes and axonal myelination compared with HI injury alone, while also significantly reducing the number of activated microglia within the white matter. UCB therapy at 5 days was not protective for oligodendrocytes or microglia, but did reduce cell death. In addition, this study is the only large animal study so far to examine the effects of UCB on oxidative stress levels, showing that UCB therapy at $12 \mathrm{~h}$ significantly reduced circulating markers of oxidative stress at $48 \mathrm{~h}$, compared with $\mathrm{HI}$ animals. A further study by $\mathrm{Li}$ et al. (32) compared the neuroprotective benefits of UCB obtained from preterm vs. term cord blood, in consideration that cellular makeup of the stem/progenitor cells of interest (as per Figure 1) is altered during gestation (13). This study showed that UCB cells from term or preterm cord blood are effective at reducing cerebral inflammation and white matter brain injury induced via a HI insult in preterm fetal sheep, but secondary mechanisms of neuroprotection are different.

A significant limitation to all of the large animal studies discussed here is they were conducted over a relatively short experimental period. In part, this is contributed by the challenges of maintaining these animals in a neonatal intensive care setting over a prolonged period, and the associated financial constraints of maintaining large animals. Consequently, large animal studies may not address the crucial need for long-term follow-up data. Another limitation that arises with large animal studies is deciphering the mechanism/s of action of UCB cells. With the limited availability of cross-reactive antibodies and molecular probes available for sheep and rabbits, compared with rodent and human studies, it makes it difficult to fully characterize pathways that therapies may be modulating. This includes what cell types within UCB may be the most effective cells to treat a specific condition, which is a consideration when moving toward "off-the-shelf" standardized products.

\section{OPTIMAL TIMING OF UCB THERAPY}

A common finding between all three large animal studies reported above was that, when UCB cells were given as an early intervention therapy, within hours after HI injury, UCB reduced brain injury. However, each study employed a different administration time point from hours to days after the HI insult, so what lessons can be taken from this? In both the term and preterm sheep studies, cells were administered at $12 \mathrm{~h}$ after injury and significant protection of the gray and white matter, respectively, was observed $(28,30)$. Delaying UCB administration to 5 days after HI insult reduced their efficacy, but significant neuroprotection was still observed (30). In contrast, in the rabbit study UCB cells were administered 9 days after preterm $\mathrm{HI}$ insult, which was $4 \mathrm{~h}$ after birth. This is a clinically relevant time point, considering that therapeutic intervention for infants born preterm may not occur until some hours after birth, when the baby has been stabilized. In addition, the exact timing of treatment will still be dependent on the time required for diagnosis of encephalopathy and, for the clinical trials, will include the time required to gain parental consent. Nevertheless, these are encouraging results, and should guide the development of early intervention therapy for the treatment of infants born preterm and with high risk of brain injury.

\section{OPTIMAL ADMINISTRATION ROUTE; DO CELLS HAVE TO REACH THE BRAIN?}

An important consideration raised by the Drobyshevsky study (30) relates to the administration protocol, as the authors found that their high dose of human UCB cells (5 million) was initially associated with a high mortality rate. They noted, however, that mortality was decreased when they increased the duration of cell infusion. A potential reason for this high mortality rate could be because of the route of administration that was used. In their study, the route chosen was intravenous; therefore, the "first pass" of the cells was via the pulmonary circulation, before the cells traveled through the rest of the body. There is good evidence in rodent models of stem cell administration that this "first pass" is critical because of the high risk of cell entrapment within the lung vasculature, leading to subsequent pulmonary embolism and, consequently, high mortality rates $(33,34)$. This risk increases as the number of cells given is increased (35). In comparison, the Aridas study (29) used administration via the brachial artery, resulting in cells being delivered initially directly into the ascending aorta. This means that the cells passed via the brain before reaching the pulmonary circulation, potentially increasing the chance of entry of cells into the brain. The challenges with this route include the increased risk of cerebral embolism in the capillary network, which may have catastrophic effects, including hemorrhage. However, there was no evidence of any increased risk of brain bleeds following brachial administration of UCB cells in this 


\section{Review | McDonald et al.}

study (28). It should, however, be considered that the brachial artery route would not be used clinically, and this must be taken into account when determining the optimum route and dose for administration of UCB. Reassuringly, data from the clinical trials assessing safety have clearly shown that judicial intravenous administration of UCB, with doses up to 50 million cells $/ \mathrm{kg}$ body weight to babies (36) and children $(37,38)$ is safe and feasible, and pulmonary embolism has not been reported.

All studies reported herein examined potential engraftment of cells within the brain, using different techniques such as immunofluorescence, MRI, and PCR, and all studies concluded that UCB cell engraftment is a relatively rare event and involves only small numbers of cells. Aridas et al. investigate the presence of fluorescently labeled UCB cells in the brain $60 \mathrm{~h}$ after administration and found a very small number of cells within the subcortical white matter, hippocampus, and cortex (29). Li et al. also used fluorescently labeled cells and only found minimal presence of cells within the brain at 10 days post administration (31). Drobyshevsky et al. examined cell engraftment via MRI, and found no evidence of cells within the brain. They also used PCR to identify the presence of a human gene and detected a faint signal, but they were not able to quantify the number of cells present and concluded that it was likely to be small in number (30). Given that all studies used methods that involved passive labeling of cells, where the signal would be diluted with each population doubling, there is the possibility that the low rate of engraftment may be partly due to loss of signal if studied some time after administration. Studies using transduction with lentiviral labels might be a more robust approach. It is pertinent to note that a study in an adult rodent model of stroke showed that, even when UCB cells were given together with a blood-brain barrier permeabilizer (mannitol), with the aim of increasing cell entry into the brain, results showed that presence of UCB cells in the central nervous system is not necessary for neuroprotection (39). It was, however, demonstrated that UCB+mannitol co-treatment increased brain levels of neurotrophic factors, which correlated with a reduction in brain infarct in this model. These findings are strongly indicative that the benefits of UCB therapy are because of the release of trophic factors directly by the administered cells, or via stimulation of endogenous cells, which mediate cerebral repair.

\section{EVIDENCE FOR THE EFFICACY OF OTHER STEM-LIKE CELLS}

In this review we have concentrated on cells obtained from UCB; however, it is important to note that other cells with stem-like properties are being examined, and show promise, for their neuroprotective potential in the immature brain. NSCs are multipotent cells endogenously produced principally in the subventicular zone (SVZ) of the developing brain, and continue to be found in the SVZ in the adult brain. They possess the ability to self-renew and capacity to differentiate into neurons and glial cells. In neonatal rats exposed to $\mathrm{HI}$, hNSCs were administered into the forebrain at $24 \mathrm{~h}$ post $\mathrm{HI}$, and were shown to mediate microglial response, enhance axonal sprouting of neurons, and improve motor functions in rats at 1 month of age (40). Chen et al. (41) have studied the effects of clinical administration of neural stem-like cells, differentiated from autologous bone marrow-derived MSCs, to 30 children with cerebral palsy. They showed that NSC-like cell administration remained safe at 6 months post treatment, and gross motor function measures indicated improvement in motor ability at 3 and 6 months post treatment. Another cell type of interest is amnion epithelial cells (AECs), obtained from the amniotic membrane after removal of the placenta at birth. Human (h)AECs demonstrate low immunogenicity on xenogeneic administration and, indeed, rather than eliciting an adverse immune reaction in response to administration, hAECs prevent activation of both innate and adaptive immune pathways, suppress pro-inflammatory cytokines, and mediate macrophage recruitment (reviewed in (ref. 12)). In light of their strong immune modulatory and antiinflammatory effects, the neuroprotective role of hAECs has been examined in response to inflammation-induced (42-44) and HI-induced preterm brain injury in large animal (sheep) models (45). In these studies, hAECs reduced white and gray matter brain injury, mediated predominantly by the antiinflammatory effects of these cells, together with stabilization of the blood-brain barrier. Given the impressive antiinflammatory and immunomodulatory benefits of hAECs, a Phase 1 safety trial is now underway to assess whether the administration of hAECs to infants with bronchopulmonary dysplasia is beneficial (ACTRN12614000174684). Neurological assessment is not an outcome measure in the current trial, but is a critical inclusion as a secondary outcome measure in future trials, given the association between bronchopulmonary dysplasia and adverse neurodevelopmental outcome (46). There are currently no clinical trials listed to specifically examine the neuroprotective effects of hAECs.

\section{FUTURE UCB CELL THERAPY—THE RIGHT CELLS AT THE RIGHT TIME}

Traditionally, for the therapeutic use of UCB, the red blood cells and plasma are removed and the mononuclear cell fraction is administered. This fraction contains many different cell types with a variable mix of stem and progenitor cells. As previously noted, these cells include HSCs, EPCs, and MSCs $(47,48)$. UCB is also an excellent source of potent immunoregulatory cells, including Tregs and MDSCs, Figure 1 $(49,50)$. It is believed that these cells are together, the major contributors to the therapeutic effect of UCB. However, each individual UCB sample (unit) has different proportions of these cells types and, furthermore, the proportion of these cells changes throughout gestation, meaning that preterm UCB is different in cell content compared with that of term UCB $(51,52)$. There is also evidence that complications during pregnancy, such as intrauterine growth restriction, preeclampsia, and chorioamnionitis can change the proportion of stem and progenitor cells and, importantly, their characteristics (53). Of particular note, it has been shown 
that UCB collected from intrauterine growth restriction pregnancies has a reduced proportion of EPCs, and that those cells present were functionally impaired (54). Unfortunately, we still do not understand how each of these cell types individually contributes to neurorepair in the studies undertaken so far, and this information will be critical to obtain as we move toward (i) identifying which UCB samples will be the most potent and efficacious in specific clinical circumstances, and (ii) developing new specific single cell-type therapies (including allogeneic) that may be more effective, but require expansion before use.

HSCs are characterized as CD34+ cells, with the ability to self-renew and differentiate into multiple blood cell lineages (55). Until recently, the principal application of UCB centered around HSCs, and their use in treating patients with hematopoietic conditions, such as childhood cancers (55). Compared with adult bone marrow, HSCs found in UCB have longer telomeres and increased colony-forming capacity $(56,57)$. CD34+ cells derived from UCB have also been shown to significantly improve behavioral outcomes and increase neurogenesis after stroke in both adult and neonatal models $(20,58,59)$. MSCs can also be isolated from UCB and, after HSCs, are the most well-studied cell type in UCB. MSCs are potent immunomodulatory cells that secrete an array of neuro- and angiotrophic factors that make them favorable cell types for treatment of neurological conditions (60). In culture, MSCs can also be directed toward, and may spontaneously form precursor and mature neurons, and astroglial cells $(61,62)$. However, MSCs are present in term UCB samples at a very low frequency and number, with only $10-30 \%$ of human term UCB samples containing MSCs (63). EPCs can be isolated from UCB, adult peripheral blood, and bone marrow. They have the ability to form mature endothelial cells and play a critical role in promoting growth of new blood vessels and stabilizing damaged vessels (64). Both in vivo and in vitro data suggest that EPCs can also protect neural cells after a HI insult $(65,66)$. Although it is considered that the main neuroregenerative benefit of EPCs is in their ability to induce angiogenesis, they can act in a paracrine manner to secrete factors that create a favorable niche for the differentiation of other progenitor cells (67). Tregs in UCB have a predominantly naive phenotype, with an enhanced proliferative potential compared with adult-derived Tregs (68). Tregs are potent immunosuppressive cells that normally maintain selftolerance, prevent autoimmunity, and can inhibit transplant rejection and regulate immune responses during infections (69). In a stroke model, Tregs have been shown to reduce neuroinflammation and infarct size, and improve long-term neurological function (70). MDSCs are a recently discovered immunosuppressive cell, found in UCB at much higher numbers than in the peripheral blood of adults (71). Their role in neurological conditions has not yet been explored in any detail; however, their presence is linked to increased recovery in a multiple sclerosis model (72). With respect to perinatal brain injury, a recent study in which $\mathrm{HI}$ was induced in neonatal rodents demonstrated that depletion of monocytes from UCB at transplantation was associated with a reduction in motor improvement and microglial suppression, suggesting that there is a cell type within the monocyte population that has neuroprotective potential (73). Each of the UCB cell types mentioned-HSCs, MSCs, EPCs, Tregs, and MDSCs-demonstrate individual characteristics that are likely to contribute to neuroprotection and repair in the perinatal setting of brain injury. The therapeutic potential of MSCs for neonatal brain injury has been more thoroughly examined than has other cell types (reviewed in (ref. 74)), and, consequently, clinical trials are currently taking place for the administration of UCB-derived MSCs to infants with HIE and children with cerebral palsy. However, it is not yet known whether individual cell types can be isolated and expanded to provide therapeutic efficacy in the treatment of perinatal brain injury or cerebral palsy, or whether these cells work best alone or in a synergistic manner within the whole mononuclear cell fraction of UCB. Evidence supports that each of the individual stem/progenitor cell types shown in Figure 1 contributes to specific neuroprotective benefits of UCB, including anti-apoptotic, anti-inflammatory, and antioxidant effects, along with vascular remodeling and the release of neurotrophic factors to support endogenous repair. However, we should also keep in mind that it may be the synergistic effects of all of these mechanisms of action that provide an optimal and combined neuroprotective strategy for perinatal brain injury. Further animal studies should examine and compare individual UCB-derived cells for their neuroprotective potential, compared with the whole UCB mononuclear fraction, with particular reference to the timing of cell administration to target specific injurious processes.

With reference to the optimal timing of UCB therapy, we have already discussed data from large animal studies that support the use of UCB mononuclear cell therapy, within the first days (9 days) after the initial insult, as being neuroprotective, and earlier intervention $(12 \mathrm{~h})$ post-HI insult, having a greater benefit (30). These findings are supported by results in adult rodents wherein treatment with UCB at 14 days post stroke does not confer any benefit (59). This is an important consideration when assessing the efficacy of UCB cells in current clinical trials, in which the vast majority of trials (Table 1) treat children through to adults (aged 6 months to 20 years) who have been diagnosed with cerebral palsy. To the best of our knowledge, there are no published animal studies in which UCB cells have been administered at an age equivalent to childhood, in terms of brain development, after perinatal brain injury. Nevertheless, some benefits of late-intervention UCB therapy are supported in the meta-analysis undertaken by Novak et al. (26).

The mechanisms by which UCB cells may mediate neurorepair in children with already established cerebral palsy are not known; however, we and others speculate that any positive effects observed could be contributed by a combination of factors, including release of neurotrophic factors, stimulating proliferation, and recruitment of neural progenitor cells, and increasing brain structural connectivity 
(75-77). There are many questions that remain to be answered with respect to the optimal timing of stem cell therapy for treatment of neonatal brain injury, and, hopefully, to prevent cerebral palsy. Such questions will be answered only via a coordinated and complimentary approach in animal studies and human clinical trials.

\section{CONCLUSIONS}

This review of the current literature supports that UCB cell therapy demonstrates excellent potential to protect or repair brain injury in the young brain, as evidenced by results in animal studies and clinical trials. There does, however, remain much to learn about how individual UCB cells mediate specific neuroprotective contributions for perinatal brain injury. Indeed, in this review we have not explored in detail that the etiology and subsequent perinatal brain injury that causes cerebral palsy is heterogenous, with compromise that may have been antenatal, perinatal, or postnatal (or a combination of these), in infants who may have been born preterm or at term and, thus, are at different stages of brain development (78). The individual cell types contained in UCB have great anti-inflammatory, anti-apoptotic, and antioxidant potential, or may mediate repair of cerebral architecture (e.g., via vascular remodeling or re-establishment of neuronal networks), with each of these benefits important for cerebral repair under various adverse conditions. It does, however, remain unknown whether optimal neuroprotective benefit is gained when these cells are given in combination as the mononuclear cell fraction of UCB, perhaps complimenting each other's mechanisms of action, or if cells could be individually isolated and expanded as an "off-the-shelf" product for targeted therapeutic intervention. Current dogma suggests that autologous cell therapy is the gold-standard for treatment of cerebral palsy; however, it is known that the proportion of the cells of interest differ widely within individual cord blood samples, and so methodologies to standardize UCB treatment regimes for maximum efficacy may be required in the future. It is likely that the questions posed in this review are best addressed using animal models of perinatal brain injury, mirroring clinical scenarios of preterm white matter injury, intrauterine inflammation, fetal growth restriction, and term $\mathrm{HIE}$ in order to characterize optimal UCB cell therapy.

Despite the remaining questions, there is substantial evidence from preclinical and clinical trials to demonstrate that UCB therapy to prevent or treat cerebral palsy is safe and feasible. Small and large animal studies demonstrate that UCB cells are efficacious as a neuroprotective therapy, mediated via anti-inflammatory, immunomodulatory, angiogenic, antioxidant, neurotrophic factor release, and anti-apoptotic actions. Results from human clinical trials to date are also promising. Information obtained from small and large animal studies shows that early intervention of UCB cells within the first few days after the onset of injury is likely to be most efficacious, and indeed the earlier cells can be administered, the better the result. This is encouraging for conditions such as HIE or perinatal stroke that can be detected early, thus allowing timely intervention. The optimal timing for other complications in which a sentinel event is not evident, or occurs antenatally, remains relatively unknown. It is certainly encouraging that initial insights from clinical trials to treat established childhood cerebral palsy show promise. Indeed, a significant benefit of therapeutic intervention for the treatment of neonatal brain injury or cerebral palsy in childhood is that the developing brain shows remarkable neuroplasticity. In summary, we should be cautiously optimistic that UCB cell therapy will have a role in the prevention or repair of the brain injury that underlies cerebral palsy in the future. However, we should also be working in a coordinated manner toward consensus on an optimal dose, cell type, mode of delivery, timing of administration, and the potential for targeted therapy in both infants and children who are diagnosed with brain injury.

\section{STATEMENT OF FINANCIAL SUPPORT}

C.M. is supported by a National Health and Medical Research Council and Cerebral Palsy Alliance Australia Early Career Fellowship. S.L.M. is supported by a Future Fellowship from the Australian Research Council. This work is also supported by Inner Wheel Australia and the Victorian Government's Operational Infrastructure Support Program.

Disclosure: The authors declare no conflict of interest.

\section{REFERENCES}

1. Novak I, Hines M, Goldsmith S, Barclay R. Clinical prognostic messages from a systematic review on cerebral palsy. Pediatrics 2012;130: e1285-312.

2. Sellier E, Platt MJ, Andersen GL, et al. Decreasing prevalence in cerebral palsy: a multi-site European population-based study, 1980 to 2003. Dev Med Child Neurol 2016;58:85-92.

3. Van Naarden Braun K, Doernberg N, Schieve L, Christensen D, Goodman A, Yeargin-Allsopp M. Birth prevalence of cerebral palsy: a population-based study. Pediatrics 2016;137:1-9.

4. Trounson A, McDonald C. Stem cell therapies in clinical trials: progress and challenges. Cell Stem Cell 2015;17:11-22.

5. Zarzeczny A, Rachul C, Nisbet M, Caulfield T. Stem cell clinics in the news. Nat Biotechnol 2010;28:1243-6.

6. Sirchia G, Rebulla P. Placental/umbilical cord blood transplantation. Haematologica 1999;84:738-47.

7. Broxmeyer HE, Douglas GW, Hangoc G, et al. Human umbilical cord blood as a potential source of transplantable hematopoietic stem/ progenitor cells. Proc Natl Acad Sci USA 1989;86:3828-2.

8. Gluckman E, Broxmeyer HA, Auerbach AD, et al. Hematopoietic reconstitution in a patient with Fanconi's anemia by means of umbilicalcord blood from an HLA-identical sibling. N Engl J Med 1989;321: 1174-8.

9. Rocha V, Cornish J, Sievers EL, et al. Comparison of outcomes of unrelated bone marrow and umbilical cord blood transplants in children with acute leukemia. Blood 2001;97:2962-71.

10. Fruchtman SM, Hurlet A, Dracker R, et al. The successful treatment of severe aplastic anemia with autologous cord blood transplantation. Biol Blood Marrow Transplant 2004;10:741-2.

11. Kurtzberg J. A history of cord blood banking and transplantation. Stem Cells Transl Med 2017;6:1309-1.

12. Castillo-Melendez M, Yawno T, Jenkin G, Miller SL. Stem cell therapy to protect and repair the developing brain: a review of mechanisms of action of cord blood and amnion epithelial derived cells. Front Neurosci 2013;7:194.

13. Li J, McDonald CA, Fahey MC, Jenkin G, Miller SL. Could cord blood cell therapy reduce preterm brain injury? Front Neurol 2014;5:200. 


\section{Cord blood cells for cerebral palsy $\quad$ Review}

14. Newman MB, Willing AE, Manresa JJ, Sanberg CD, Sanberg PR. Cytokines produced by cultured human umbilical cord blood (HUCB) cells: implications for brain repair. Exp Neurol 2006;199:201-8.

15. Neuhoff S, Moers J, Rieks M, et al. Proliferation, differentiation, and cytokine secretion of human umbilical cord blood-derived mononuclear cells in vitro. Exp Hematol 2007;35:1119-31.

16. Fan X, Heijnen CJ, van der Kooij MA, Groenendaal F, van Bel F. The role and regulation of hypoxia-inducible factor-1alpha expression in brain development and neonatal hypoxic-ischemic brain injury. Brain Res Rev 2009;62:99-108.

17. Hau S, Reich DM, Scholz M, et al. Evidence for neuroprotective properties of human umbilical cord blood cells after neuronal hypoxia in vitro. BMC Neurosci 2008;9:30.

18. Hall AA, Guyer AG, Leonardo CC, et al. Human umbilical cord blood cells directly suppress ischemic oligodendrocyte cell death. J Neurosci Res 2009;87:333-41.

19. Jiang L, Saporta S, Chen N, Sanberg CD, Sanberg P, Willing A. The effect of human umbilical cord blood cells on survival and cytokine production by post-ischemic astrocytes in vitro. Stem Cell Rev 2010;6:523-31.

20. Chen J, Sanberg PR, Li Y, et al. Intravenous administration of human umbilical cord blood reduces behavioral deficits after stroke in rats. Stroke 2001;32:2682-8.

21. Lu D, Sanberg PR, Mahmood A, et al. Intravenous administration of human umbilical cord blood reduces neurological deficit in the rat after traumatic brain injury. Cell Transplant 2002;11:275-81.

22. Pimentel-Coelho PM, Magalhaes ES, Lopes LM, deAzevedo LC, Santiago MF, Mendez-Otero R. Human cord blood transplantation in a neonatal rat model of hypoxic-ischemic brain damage: functional outcome related to neuroprotection in the striatum. Stem Cells Dev 2010;19:351-8.

23. Geissler M, Dinse HR, Neuhoff S, Kreikemeier K, Meier C. Human umbilical cord blood cells restore brain damage induced changes in rat somatosensory cortex. PLoS ONE 2011;6:e20194.

24. Meier C, Middelanis J, Wasielewski B, et al. Spastic paresis after perinatal brain damage in rats is reduced by human cord blood mononuclear cells. Pediatr Res 2006;59:244-9.

25. Park WS, Sung SI, Ahn SY, et al. Hypothermia augments neuroprotective activity of mesenchymal stem cells for neonatal hypoxic-ischemic encephalopathy. PLoS ONE 2015;10:e0120893.

26. Novak I, Walker K, Hunt RW, Wallace EM, Fahey M, Badawi N. Concise review: stem cell interventions for people with cerebral palsy: systematic review with meta-analysis. Stem Cells Transl Med 2016;5:1014-25.

27. Bennet L, Tan S, Van den Heuij L, et al. Cell therapy for neonatal hypoxia-ischemia and cerebral palsy. Ann Neurol 2012;71:589-600.

28. Aridas JD, McDonald CA, Paton MC, et al. Cord blood mononuclear cells prevent neuronal apoptosis in response to perinatal asphyxia in the newborn lamb. J Physiol 2016;594:1421-35.

29. Drobyshevsky A, Cotten CM, Shi Z, et al. Human umbilical cord blood cells ameliorate motor deficits in rabbits in a cerebral palsy model. Dev Neurosci 2015;37:349-62.

30. Li J, Yawno T, Sutherland A, et al. Preterm white matter brain injury is prevented by early administration of umbilical cord blood cells. Exp Neurol 2016;283:179-87.

31. Azzopardi D, Edwards AD. Magnetic resonance biomarkers of neuroprotective effects in infants with hypoxic ischemic encephalopathy. Semin Fetal Neonatal Med 2010;15:261-9.

32. Li J, Yawno T, Sutherland A, et al. Term versus preterm cord blood cells for the prevention of preterm brain injury. Pediatric Research 2017;170: https//doi.org/10.1038/pr.2017.170.

33. Kean TJ, Lin P, Caplan AI, Dennis JE. MSCs: delivery routes and engraftment, cell-targeting strategies, and immune modulation. Stem Cells Int 2013;2013:732742.

34. Anjos-Afonso F, Siapati EK, Bonnet D. In vivo contribution of murine mesenchymal stem cells into multiple cell-types under minimal damage conditions. J Cell Sci 2004;117:5655-64.

35. Lee RH, Seo MJ, Pulin AA, Gregory CA, Ylostalo J, Prockop DJ. The CD34-like protein PODXL and alpha6-integrin (CD49f) identify early progenitor MSCs with increased clonogenicity and migration to infarcted heart in mice. Blood 2009;113:816-26.

36. Cotten CM, Murtha AP, Goldberg RN, et al. Feasibility of autologous cord blood cells for infants with hypoxic-ischemic encephalopathy. J Pediatr 2014;164:e971.

37. Romanov YA, Tarakanov OP, Radaev SM, et al. Human allogeneic AB0/ Rh-identical umbilical cord blood cells in the treatment of juvenile patients with cerebral palsy. Cytotherapy 2015;17:969-78.

38. Min K, Song J, Kang JY, et al. Umbilical cord blood therapy potentiated with erythropoietin for children with cerebral palsy: a double-blind, randomized, placebo-controlled trial. Stem Cells 2013;31: 581-91.

39. Borlongan CV, Hadman M, Davis Sanberg C, Sanberg PR. Central nervous system entry of peripherally injected umbilical cord blood cells is not required for neuroprotection in stroke. Stroke 2004;35:2385-9.

40. Daadi MM, Davis AS, Arac A, et al. Human neural stem cell grafts modify microglial response and enhance axonal sprouting in neonatal hypoxicischemic brain injury. Stroke 2010;41:516-23.

41. Chen G, Wang Y, Xu Z, et al. Neural stem cell-like cells derived from autologous bone mesenchymal stem cells for the treatment of patients with cerebral palsy. J Transl Med 2013;11:21.

42. Yawno T, Schuilwerve J, Moss TJM, et al. Human amnion epithelial cells reduce fetal brain injury in response to intrauterine inflammation. Dev Neurosci 2013;35:272-82.

43. Yawno T, Sabaretnam T, Li J, et al. Human amnion epithelial cells protect against white matter brain injury after repeated endotoxin exposure in the preterm ovine fetus. Cell Transplant 2017;26:541-3.

44. Barton SK, Melville JM, Tolcos M, et al. Human amnion epithelial cells modulate ventilation-induced white matter pathology in preterm lambs. Dev Neurosci 2015;37:338-48.

45. Van den Heuij L, Fraser M, Miller S, et al. Delayed intranasal infusion of human amnion epithelial cells improves white matter maturation after asphyxia in preterm fetal sheep. J Cereb Blood Flow Metab 2017:271678X17729954.

46. Natarajan G, Pappas A, Fau - Shankaran S, Shankaran S, Fau - Kendrick $\mathrm{DE}$, et al. Outcomes of extremely low birth weight infants with bronchopulmonary dysplasia: impact of the physiologic definition. 2012;88:509-15.

47. Broxmeyer HE. Biology of cord blood cells and future prospects for enhanced clinical benefit. Cytotherapy 2005;7:209-18.

48. Phuc PV, Ngoc VB, Lam DH, Tam NT, Viet PQ, Ngoc PK. Isolation of three important types of stem cells from the same samples of banked umbilical cord blood. Cell Tissue Bank 2012;13:341-51.

49. McDonald CA, Castillo MM, Penny TR, Jenkin G, Miller SL. Umbilical Cord Blood Cells for Perinatal Brain Injury: The Right Cells at the Right Time?, Umbilical Cord Blood Banking for Clinical Application and Regenerative Medicine, Prof. Ana Colette Maurício (Ed.) 2017: InTech: https//doi.org/10.5772/66647.

50. Tolar J, Hippen KL, Blazar BR. Immune regulatory cells in umbilical cord blood: $\mathrm{T}$ regulatory cells and mesenchymal stromal cells. Br J Haematol 2009;147:200-6.

51. Baker CD, Ryan SL, Ingram DA, Seedorf GJ, Abman SH, Balasubramaniam V. Endothelial colony-forming cells from preterm infants are increased and more susceptible to hyperoxia. Am J Respir Crit Care Med 2009;180:454-61.

52. Javed MJ, Mead LE, Prater D, et al. Endothelial colony forming cells and mesenchymal stem cells are enriched at different gestational ages in human umbilical cord blood. Pediatr Res 2008;64:68-73.

53. Monga R, Buck S, Sharma P, Thomas R, Chouthai NS. Effect of preeclampsia and intrauterine growth restriction on endothelial progenitor cells in human umbilical cord blood. J Matern Fetal Neonatal Med 2012;25:2385-89.

54. Sipos PI, Bourque SL, Hubel CA, et al. Endothelial colony-forming cells derived from pregnancies complicated by intrauterine growth restriction are fewer and have reduced vasculogenic capacity. J Clin Endocrinol Metab 2013;98:4953-60. 
55. Rogers I, Casper RF. Umbilical cord blood stem cells. Best Pract Res Clin Obstet Gynaecol 2004;18:893-908.

56. Vaziri H, Dragowska W, Allsopp RC, Thomas TE, Harley CB, Lansdorp PM. Evidence for a mitotic clock in human hematopoietic stem cells: loss of telomeric DNA with age. Proc Natl Acad Sci USA 1994;91:9857-60.

57. Nakahata T, Ogawa M. Hemopoietic colony-forming cells in umbilical cord blood with extensive capability to generate mono- and multipotential hemopoietic progenitors. J Clin Invest 1982;70:1324-8.

58. Verina T, Fatemi A, Johnston MV, Comi AM. Pluripotent possibilities: human umbilical cord blood cell treatment after neonatal brain injury. Pediatr Neurol 2013;48:346-54.

59. Boltze J, Reich DM, Hau S, et al. Assessment of neuroprotective effects of human umbilical cord blood mononuclear cell subpopulations in vitro and in vivo. Cell Transplant 2012;21:723-37.

60. Caplan AI, Dennis JE. Mesenchymal stem cells as trophic mediators. J Cell Biochem 2006;98:1076-84.

61. Deng J, Petersen BE, Steindler DA, Jorgensen ML, Laywell ED. Mesenchymal stem cells spontaneously express neural proteins in culture and are neurogenic after transplantation. Stem Cells 2006;24:1054-64.

62. Woodbury D, Schwarz EJ, Prockop DJ, Black IB. Adult rat and human bone marrow stromal cells differentiate into neurons. J Neurosci Res 2000;61:364-70.

63. Kogler G, Sensken S, Wernet P. Comparative generation and characterization of pluripotent unrestricted somatic stem cells with mesenchymal stem cells from human cord blood. Exp Hematol 2006;34:1589-95.

64. Melero-Martin JM, Khan ZA, Picard A, Wu X, Paruchuri S, Bischoff J. In vivo vasculogenic potential of human blood-derived endothelial progenitor cells. Blood 2007;109:4761-8.

65. Tanaka N, Kamei N, Nakamae T, et al. CD133+ cells from human umbilical cord blood reduce cortical damage and promote axonal growth in neonatal rat organ co-cultures exposed to hypoxia. Int J Dev Neurosci 2010;28:581-7.

66. Ding J, Zhao Z, Wang C, et al. Bioluminescence imaging of transplanted human endothelial colony-forming cells in an ischemic mouse model. Brain Res 2016;1642:209-18.

67. Liu Y, Teoh SH, Chong MS, et al. Vasculogenic and osteogenesisenhancing potential of human umbilical cord blood endothelial colonyforming cells. Stem Cells 2012;30:1911-24.
68. Takahata Y, Nomura A, Takada H, et al. CD25+CD4+ T cells in human cord blood: an immunoregulatory subset with naive phenotype and specific expression of forkhead box p3 (Foxp3) gene. Exp Hematol 2004;32:622-9.

69. Sakaguchi S. Naturally arising Foxp3-expressing CD25+CD4+ regulatory $\mathrm{T}$ cells in immunological tolerance to self and non-self. Nat Immunol 2005;6:345-52.

70. Li P, Gan Y, Sun BL, et al. Adoptive regulatory T-cell therapy protects against cerebral ischemia. Ann Neurol 2013;74:458-71.

71. Gervassi A, Lejarcegui N, Dross S, et al. Myeloid derived suppressor cells are present at high frequency in neonates and suppress in vitro $\mathrm{T}$ cell responses. PLoS ONE 2014;9:e107816.

72. Moline-Velazquez V, Cuervo H, Vila-Del Sol V, Ortega MC, Clemente D, de Castro F. Myeloid-derived suppressor cells limit the inflammation by promoting $\mathrm{T}$ lymphocyte apoptosis in the spinal cord of a murine model of multiple sclerosis. Brain Pathol 2011;21:678-91.

73. Womble TA, Green S, Shahaduzzaman M, et al. Monocytes are essential for the neuroprotective effect of human cord blood cells following middle cerebral artery occlusion in rat. Mol Cell Neurosci 2014;59:76-84.

74. van Velthoven CT, Kavelaars A, Heijnen CJ. Mesenchymal stem cells as a treatment for neonatal ischemic brain damage. Pediatr Res 2012;71: 474-81.

75. Englander ZA, Sun J, Laura C, Mikati MA, Kurtzberg J, Song AW. Brain structural connectivity increases concurrent with functional improvement: evidence from diffusion tensor MRI in children with cerebral palsy during therapy. Neuroimage Clin 2015;7:315-24.

76. Zhao F, Qu Y, Liu H, Du B, Mu D. Umbilical cord blood mesenchymal stem cells co-modified by TERT and BDNF: a novel neuroprotective therapy for neonatal hypoxic-ischemic brain damage. Int J Dev Neurosci 2014;38:147-54.

77. Wang XL, Zhao YS, Hu MY, Sun YQ, Chen YX, Bi XH. Umbilical cord blood cells regulate endogenous neural stem cell proliferation via hedgehog signaling in hypoxic ischemic neonatal rats. Brain Res 2013;1518:26-35.

78. Phillips AW, Johnston MV, Fatemi A. The potential for cell-based therapy in perinatal brain injuries. Transl Stroke Res 2013;4:137-48. 